\title{
PENGARUH KEMAMPUAN MANAJEMEN DAN POLA PENDAMPINGAN TERHADAP PENGEMBANGAN USAHA MELALUI JEJARING PASAR (STUDI PADA USAHA KECIL DAN MENENGAH DI KABUPATEN BALANGAN)
}

\author{
Muhamad Salman \\ Sekolah Tinggi Ilmu Ekonomi Pancasetia Banjarmasin. \\ Jl. Ahmad Yani Km. 5.5 Banjarmasin \\ salmanalfathah@gmail.com
}

Abstract: This study aims to determine both partially and simultaneously how much influence the management ability and mentoring pattern have on business development through market networks (Studies on Small and Medium Enterprises in Balangan Regency) and the variables that influence both directly and indirectly on market development.

The method used in this study is a quantitative method and with a population of 5,124 (five thousand one hundred and twenty-four) UMKM, samples were taken using a proportionate stratified random sampling technique using the Slovin formula as many as 98 UMKM, the research instrument was validity and reliability test, the data were tested using linear regression Path analysis using Smart PLS.

The results of this study indicate that there is a direct influence of Management Ability, Assistance Pattern and Market Networking influence on Business Development and indirect influence on Management Ability, on Business Development through market networks and does not affect Development Pattern on Business Development through market networks.

Keywords: management ability, mentoring pattern, market network and business development.

Abstrak: Penelitian ini bertujuan untuk mengetahui baik secara parsial dan simultan seberapa besar Pengaruh Kemampuan Manajemen Dan Pola Pendampingan Terhadap Pengembangan Usaha Melalui Jejaring Pasar (Studi Pada Usaha Kecil Dan Menengah Di Kabupaten Balangan) serta variabel yang berpengaruh Baik itu secara langsung dan tidak langsung terhadap pengembangan pasar.

Metode yang digunakan dalam penelitian ini adalah metode kuantitatif dan dengan populasi sebanyak 5.124 (lima Ribu Seratus Dua Puluh Empat) UMKM, diambil sampel dengan teknik proportionate stratified random sampling dengan menggunakan rumus Slovin sebanyak 98 UMKM, instrument penelitian uji validitas dan uji reliabilitas, data - data diuji dengan menggunakan regresi linear Analisis Jalur menggunakan Smart PLS.

Hasil penelitian ini menunjukkan bahwa terdapat pengaruh secara langsung Kemampuan Manajemen, Pola Pendampingan dan Jejaring Pasar berpengaruh terhadap Pengembangan Usaha dan tidak langsung Kemampuan Manajemen, terhadap Pengembangan Usaha melalui jejaring pasar dan tidak berpengaruh Pola Pengembangan terhadap Pengembangan Usaha melalui jejaring pasar.

Kata kunci : kemampuan manajemen, pola pendampingan, jejaring pasar dan pengembangan usaha. 


\section{Latar Belakang Masalah}

Selain itu, selama ini pola pendampingan dari pihak terkait belum mampu membantu UKM kearah yang lebih baik yang disebabkan diantaranya adalah karena kurangnya tenaga pendamping serta kurang optimalnya para tenaga pendamping dalam memberikan pendampingan, dan harusnya dapat beradaptasi serta dapat memahami karakteristik dan budaya UKM yang didampinginya, sebagai contoh para pendamping harus mampu mengunakan bahasa daerah setempat dalam memberikan pendampingan, hal ini penting agar memudahkan penyampaian pesan, sehingga pesan dapat disampaikan secara efektif. Selain itu selama ini para tenaga pendamping kurang memahami budaya lokal, hal tersebut membuat pola pendampingan kurang berjalan optimal. Menurut Deptan (2010:40), tujuan dari pendampingan antara lain memperkuat dan memperluas kelembagaan yang sedang dijalankan dimasyarakat, menumbuhkan dan menciptakan strategi agar berjalan dengan lancar dan tercapai tujuan yang dijalankan dan meningkatkan peran serta aparat maupun tokoh masyarakat dalam melaksanakan program pendampingan. Menurut Wiryasaputra, (2013:60), tujuan pendampingan adalah pemberdayaan. Pemberdayaan berarti mengembangkan kekuatan atau kemampuan (daya), potensi, sumber daya manusia yang ada pada diri manusia agar mampu membela dirinya sendiri. Didalam kegiatan pendampingan perlu memiliki tujuan dan sasaran yang jelas dan dapat dilihat hasilnya. Sejalan dengan hal tersebut Eka Dwi Puji Astuti, 2015, penelitiannya menyatakan, pola pendampingan pemerintah berpengaruh signifikan baik secara simultan maupun parsial terhadap kemajuan usaha UKM di Kabupaten Banjar.

Sehubungan dengan hal tersebut, berikut data penelitian UKM yang sudah mendapatkan pendampingan dan yang belum mendapat pendampingan di lokasi peneltian, dapat dijelaskan sebagai berikut: Tabel 1.1
Data UKM Yang Mendapat Pendampingan dan Yang Belum Pendampingan
Kabupaten Balangan

\begin{tabular}{l|c|c|c}
\hline \multicolumn{1}{c|}{ Klaster Usaha } & UKM & Pendampingan & Belum \\
\hline \hline Makanan dan Minuman & 12 & 9 & 3 \\
\hline Pertanian & 11 & 9 & 2 \\
\hline Peternakan & 12 & 10 & 2 \\
\hline Bangunan & 12 & 4 & 8 \\
\hline Jasa & 12 & 6 & 6 \\
\hline Kerajinan & 12 & 8 & 4 \\
\hline Teksil & 12 & 7 & 5 \\
\hline Otomotif & 11 & 5 & 6 \\
\hline Teknologi Internet & 4 & 1 & 3 \\
\hline \hline Jumlah & 98 & 59 & 39 \\
\hline \hline Sumber: Dinas koperasi, UKM dan Perindustrian Kabupaten Balangan (2020)
\end{tabular}

Bila dilihat dari data perbandingan antara UKM yang mendapatkan pendampingan dengan yang tidak mendapatkan pendampingan terlihat dari 98 sampel penelitian dari UKM sebanyak 59 UKM sudah mendapatkan pendampingan dan sebanyak 39 UKM belum mendapatkan pendampingan UKM, artinya bahwa masih banyak UKM yang belum mendapatkan bantuan dan pendampingan dari instansi terkait.

Terkait problematika permasalahan tersebut dalam hal pemasaran, UKM yang ada di Kabupaten Balangan pun selama ini terkesan hanya mampu memasuki sebatas pasar lokal saja atau pemasaran produk hanya terbatas pada pangsa pasar di Kabupaten Balangan saja, hal ini terlihat jejaring pasar belum terbentuk secara optimal. Sejalan dengan uraian tersebut materi permasalahan menitik beratkan pada faktor kompetensi SDM, kemampuan manajerial dan pola pendampingan yang berdampak terhadap pengembangan usaha UMKM, maka peneliti tertarik untuk mengangkat masalah tersebut kedalam sebuah penelitian dengan judul Pengaruh Kemampuan Manajemen Dan Pola Pendampingan Terhadap Pengembangan Usaha Melalui Jejaring Pasar (Studi Pada Usaha Kecil Dan Menengah Di Kabupaten Balangan)

\section{Studi Literatur \\ Kemampuan Manajemen}

Kemampuan menunjukkan karakteristik pengetahuan dan keterampilan yang dimiliki atau dibutuhkan oleh setiap individu untuk meningkatkan mereka untuk melakukan tugas dan tanggung jawab mereka secara efektif dan meningkatkan standar kualitas profesional dalam pekerjaan mereka. Kemampuan menjelaskan apa yang dilakukan orang di tempat kerja pada berbagai tingkatan dan merinci standar masingmasing tingkatan, mengindentifikasi karakteristik, 
pengetahuan dan keterampilan yang diperlukan oleh individu yang memungkinkan menjalankan.

$$
\text { Rivai (2009:217) menjelaskana }
$$

kemampuan berhubungan erat dengan kemampuan fisik dan mental yang dimiliki orang dalam melaksanakan pekerjaan. Kemampuan karyawan rendah akan menggunakan waktu dan usaha lebih besar dari pada karyawan yang berkemampuan tinggi untuk menyelesaikan suatu pekerjaan. Setiap jenis pekerjaan menurut pengetahuan, keterampilan dan sikap tertentu agar dapat melaksanakan pekerjaan dengan baik.

Menurut Rivai (2013:40) banyak faktor yang menyebabkan perlu mengetahui dan memiliki kemampuan manajemen dalam mengelola organsiasi agar dapat menghasilkan kinerja yang diharapkan dalam memimpin kelompoknya. Indikatornya antara lain karena ia ;

a. Kurang memahami kinerja yang diharapkan dari posisinya sebagai seorang pimpinan kelompok kerja.

b. Profesionalisme dalam bekerja rendah

c. Jalur komunikasi yang kurang baik

d. Kurang memahami peran manajerial yang disandangnya.

e. Tidak mempunyai keterampilan manajerial yang diperlukan untuk menghasilkan kinerja manajerial yang ditargetkan.

f. Kompetensi diri rendah

g. Lemah dalam hal memotivasi atau menggerakkan orang-orang yang dipimpinnya.

Dikutip dari https://www.jurnal.id menjelaskan ada 10 indikator yang harus diketahui terhadap kemampuan manajemen yang harus dimiliki, yaitu:

1. Kemampuan emosi

Kemampuan ini adalah kemampuan untuk dapat mengontor emosi secara baik dalam menghadapi karakteristik manusia disekitar.

2. Kemampuan mengelola SDM

Kemampuan dalam menjalankan aktivitas secara sitematis, teroganisir dan rapi sehingga proses bekerja akan berjalan lebih terarah dan sesuai dengan target dan tujuan.

3. Memiliki strategi manajerial

Seorang pemimpin yang baik harus dapat menuangkan impiannya ke dalam ide-ide yang dapat diimpleentasikan melalui perencanaan strategis manajemen yang efektif dan efesien

4. Memiliki jiwa kepemimpinan
Pemimpin yang baik harus bisa menginspitrasi dan memberikan dorongan positif pada teamworknya. Bersedia untuk terlibat dan bertanggungjawab dalam pemecahan masalah serta berani mengamambil resiko.

5. Mengelola waktu dengan baik

Seornag pemimpin bisnis harus bisa mengelola waktu dengan baik, mulai dari mengerjakan tugas berdasarkan prioritas atau pun disiplin dengan jadwal yang telah ditetapkan baik untuk jangka pendek maupun jangka panjang.

6. Komunikatif

Seorang manajerial harus mempunyai dan mampu berkomunikasi dengan baik kepada staf maupun rekan kerja serta mitra kerjaagar memudahkan dalam arahan dan negosiasi.

7. Inovatif

Keterampilan manajerial yang wajib dimiliki sebagai suaha ingin berambah lebih lama dalam menghadapi kerasnya sebuah persaingan bisnis kreativitas dama membuat inovasi terhadap produk dan jasa harus dimiliki.

8. Strategi pemasaran yang jitu

Menyusun konsep strategi pemasaran yang handal sermat dalam menentukan target pasar dan menerapkan bauran pemasaran wajib dipahami.

9. Reputasi yang baik

Seorang bisnis harus memiliki reputasi yang baik agar dapat mempangaruhi reputasi brand produk yang mau dijual

10. Pengelolaan keuangan

Keterampilan dalam mengelola keuangan sangatlah penting sebab keuangan adalah salah satu faktor penentu berjalan tidaknya kegiatan usaha oleh sebab itulah pengelolaan keuangan harus dilakukan dengan baik dan benar.

Menurut Royan (2010:89) menjelaskan kemampuan manajemen dasar yang dibutuhkan oleh organisasi internal perusahaan, yaitu:

a. Kemampuan konseptual

Kemampuan dalam memiliki visi dan misi kedepan yang jelas dengan program yang akurat serta menjaga kompetitive advantage dalam internal organisasi.

b. Kemampuan dalam berkomunikasi 
Dalam hal ini kemampuan yang harus dimiliki adalah kemampuan komunikasi dengan semua orang akan mendorong orang yang disekitar kita menjadi tim terbaik.

c. Keterampilan teknis

Memiliki kemampuan dalam bidang informasi dan teknis merupakan hal yang sangt penting dalam menunjang kegiatan bisnis dengan memahami konsep teknis pekerjaan.

d. Keterampilan dalam manajemen waktu

Seorang pemimpin atau manajerial harus mampu dalam mengalokasikan dan membagi waktunya agar bisa mendapatkan hasil yang lebih optimal. Kemampuan ini menyusun perencanaan project dan lain sebaginya sesuai waktu perencanaan.

e. Keterampilan dalam membuat keputusan bisnis

Kemampaun dalammendefinisikan permasalahan dan dapat meninjau ulang secara lebih komprehensiftermasuk juga dalam memberikan solusi agar dapat memecahkan permasalahan.

f. Kemampuan dalam bidang kepemimpinan

Dalam hal ini seorang pemimpin harus mempunyai kemampuan untuk memimpin organisasi untuk mendorong terciptanya kepercayaan pada lingkungan kerjanya dan menciptakan teamwork yang benar-benar solid pad atim yang berada dibawah pimpinannya.

\section{Pola Pendampingan}

Pola dalam Kamus Besar Bahasa Indonesia artinya sistem, cara kerja, bentuk (struktur) yang tetap. Dan dalam Wikipedia Indonesia adalah bentuk atau model (atau, lebih abstrak, suatu set peraturan) yang bisa dipakai untuk membuat atau untuk menghasilkan suatu atau bagian dari sesuatu, khususnya jika sesuatu yang ditimbulkan cukup mempunyai suatu yang sejenis untuk pola dasar yang dapat ditunjukkan atau terlihat, yang mana sesuatu itu dikatakan memamerkan pola itu sendiri.

Banyak cara melakukan pendampingan dan salah satunya melalui kunjungan ke lapangan, tujuan kunjungan kelapangan ini adalah membina hubungan kedekatan dengan masyarakat, kedekatan dapat menimbulkan kepercayaan antar pendamping dengan yang didampingi. Menurut
Deptan (2010:40), tujuan dari pendampingan antara lain:

1. Memperkuat dan memperluas kelembagaan yang sedang dijalankan dimasyarakat.

2. Menumbuhkan dan menciptakan strategi agar berjalan dengan lancar dan tercapai tujuan yang dijalankan.

3. Meningkatkan peran serta aparat maupun tokoh masyarakat dalam melaksanakan program pendampingan.

Menurut Wiryasaputra (2013:86), dalam menanggapi keprihatinan itu pada dasarnya pendamping sebagai fasilitator perubahan dalam proses pendampingan yang dapat memfungsikan diri dalam berbagai cara :

\section{Menyembuhkan}

Fungsi ini dipakai oleh pendamping ketika melihat keadaan yang perlu dikembalikan ke keadaan semula. Hal ini untukmembantu orang yang didampingi, menghilangkan gejala atau tingkah laku yang disfungsional.

5. Menopang

Fungsi ini untuk membantu orang yang didampingi menerima keadaan sekarang sebagaimana adanya. Misalnya peristiwa kehilangan seseorang yang dicintainya. Klien dibantu agar tidak larut kedalam halusinasi atau delusi yang berkepanjangan, melainkan dibantu untuk menghilangkan rasa kehilangan dan kedukaannya secara penuh dan utuh sehingga dapat menerima keadaan yang baru.

6. Membimbing

Fungsi membimbing ini dilakukan pada waktu orang harus mengambil keputusan tertentu tentang masa depannya. Dalam hal ini bersama orang yang didampingi melihat segi positif dan negative setiap kemungkinan pemecahan masalah.

7. Memperbaiki hubungan

Fungsi ini dipakai oleh pendamping untuk membantu orang yang didampingi bila mengalami konflik batin dengan pihak lain yang mengakibatkan putusnya atau rusaknya hubungan. Dalam fungsi ini pendamping berperan sebagai mediator atau penengah yang memfasilitasi pihak yang terlibat dalam konflik untuk membicarakannya.

8. Memberdayakan/memperkuat Fungsi ini dipakai untuk membantu orang yang didampingi menjadi penolong bagi dirinya sendiri pada masa depan ketika menghadapi 
kesulitan kembali. Dengan demikian orang yang didampingi diharapkan tidak selalu tergantung pada pertolongan orang lain.

Menurut Bintan, (2010:89) didalam proses pelaksanaan pendampingan harus memiliki metode Pendampingan yang harus disesuaikan dengan keadaan masyarakat yang harus didampinngi. Metode pendampingan ini merupakan proses kegiatan agar terjadinya pendampingan, metode pendampingan yang biasa digunakan dalam kegiatan pendampingan, yaitu:

a) Konsultasi adalah upaya pembantuan yang diberikan pendamping terhadap masyarakat dengan cara memberikan jawaban, solusi dan pemecahan masalah yang dibutuhkan oleh masyarakat.

b) Pembelajaran adalah alih pengetahuan dan sistem nilai yang dimiliki oleh pendamping kepada masyarakat dalam proses yang disengaja.

c) Konseling Adalah membantu menggali semua masalah dan potensi yang dimiliki dan membuka alternatif-alternatif solusi untuk mendorong masyarakat mengambil keputusan berdasarkan pertimbangan yang ada dan harus berani bertanggung jawab bagi kehidupanmasyarakat.

Edi (2009:187) menjelaskan bahwa indicator pendampingan yakni berpusat pada empat bidang tugas atau fungsi, yaitu:

a. Pemungkinan (Enabling) atau fasilitasi Merupakanfungsi yang berkaitan dengan pemberian motivasi dan kesempatan bagi masyarakat, beberapaa tugas yang berkaitan dengan fungsi ini antara lain menjadi model, melakukan mediasi dan negosiasi, membangun konsensus bersama, serta melakukan manajemen sumber.

b. Penguatan (Empowering) Penguatan merupakan fungsi yang berkaitan dengan pendidikan dan pelatihan guna memperkuat kapasitas masyarakat. Pendamping berperan aktif sebagai agen yang memberi masukan positif dan direktif berdasarkan pengetahuan dan pengalaman serta bertukar gagasan dengan pengetahuan pengalaman masyarakat yang didampinginya, membangkitkan kesadaran masyarakat, meyampaikan informasi, melakukan konfrontasi, menyelenggarakan pelatihan bagi masyarakat adalah beberapa tugas yang berkaitan dengan fungsi penguatan. c. Perlindungan (Protecting) Merupakan fungsi yang berkaitan dengan interaksi pendamping dengan lembaga-lembaga eksternal atas nama dan demo kepentingan masyarakat yang didampinginya. Pendamping dapat bertugas mencari sumber-sumber, melakukan pembelaan, menggunakan media, meningkatkan hubungan masyarakat, dan membangun jaringan kerja. Fungsi perlindungan juga menyangkut tugas pendamping sebagai konsultan dalam pemecahan masalah yang dihadapi para anggota.

d. Pendukungan (Supporting) Mengacu pada keterampilan yang bersifat praktis yang dapat mendukung terjadinya perubahan positif pada masyarakat. Pendamping dituntut tidak hanya mampu menjadi manajer perubahan dalam mengorganisasi kelompok yang didampingi, melainkan pula mampu melaksanakan tugastugas sesuai dengan berbagai keterampilan dasar yang dimiliki. Dalam menjalankan suatu usaha perlu adanya pendampingan agar usaha yang dikelola masing-masing anggota masyarakat dapat berjalan dengan baik dan dapat berkembang dengan baik. Hal tersebut juga dapat berdampak positif dalam perkembangan usaha yang membawa pada peningkatan kesejahteraan para anggota.

\section{Jejaring Pasar}

Menurut Dimas (2011:45) jaringan adalah sebuah ruang lingkup kegiatan yang mana terkumpulnya beberapa orang untuk melakukan kegiatan tertentu.

Dalam kehidupan sehari-hari, keberadaan pasar sangatlah penting. Hal ini dikarenakan apabila ada kebutuhan yang tidak dapat dihasilkan sendiri, maka kebutuhan tersebut dapat diperoleh di pasar. Para konsumen atau pembeli datang ke pasar untuk berbelanja dan memenuhi kebutuhannya dengan membawa sejumlah uang guna membayar harganya.

Pasar adalah salah satu dari berbagai sistem, institusi, prosedur, hubungan sosial dan infrastruktur di mana usaha menjual barang, jasa dan tenaga kerja untuk orang-orang dengan imbalan uang. Barang dan jasa yang dijual menggunakan alat pembayaran yang sah yaitu uang. Pasar bervariasi dalam ukuran, jangkauan, skala geografis, lokasi jenis dan berbagai 
komunitas manusia, serta jenis barang dan jasa yang diperdagangkan.

Menurut Widyawati, (2011:65) pasar yang berfungsi sebagai tempat atau wadah untuk pelayanan bagi masyarakat. Hal ini dapat dilihat dari berbagai segi atau bidang diantaranya:

a. Segi Ekonomi

Merupakan tempat transaksi antara produsen dan konsumen yang merupakan komoditas untuk mewadahi kebutuhan sebagai demand dan suplai.

b. Segi Sosial Budaya

Merupakan kontrak sosial secara langsung yang menjadi tradisi suatu masyarakat yang merupakan interaksi antara komunitas pada sektor informal dan formal.

c. Segi Arsitektur

Menunjukkan ciri khas daerah, yang menampilkan bentuk-bentuk fisik bangunan dan artefak yang dimiliki.

Menurut Soesilo, (2011:66) jenis pasar ini dibagi menjadi 2 yaitu pasar nyata atau pasar tidak nyata. Berikut penjelasannya :

9. Pasar Nyata Pasar nyata

merupakan sebuah pasar dimana terdapat berbagai jenis barang yang diperjualbelikan serta dapat dibeli oleh pembeli. Contoh dari pasar nyata ialah pasar swalayan dan pasar tradisional.

10. Pasar Abstrak

Pasar abstrak merupakan sebuah pasar dimana terdapat para pedagang yang tidak menawar berbagai jenis barang yang dijual serta tidak membeli secara langsung, namun hanya menggunakan surat dagangan saja. Contoh dari pasar abstrak adalah pasar online, pasar modal, pasar valuta asing, dan pasar saham.

Menurut Malita (2011:89) indikator jejaring pasar yang dapat digunakan yaitu melalui sosial media mendiskripsikan teknologi online dan kebiasaan orang-orang yang menggunakannya untuk berbagi pendapat, wawasan,pengalaman dan pandangan, yaitu:

1. Facebook merupakan salah satu situs jejaring sosial yang sangat popular di dunia saat ini.

2. Twitter juga merupakan salah satu jenis situs jejaring sosial yang popular di dunia saat ini. Twitter sendiri adalah jejaring sosial dan micro-blogging yang memfasilitasi penggunannya dapat memperbarui atau memberikan update informasi tentang pengguna, bisnis, organisasi, dan lain sebagainya.

3. Instagram Sama halnya dengan facebook dan twitter Instagram merupakan salah satu situs jejaring sosial yang juga popular di dunia. Berdasarkan data yang diperoleh pada

4. Whatsapp : Aplikasi pesan untuk smartphone dengan basic mirip Blackberry Messenger

5. Line : Sebuah aplikasi pengirim pesan instan gratis yang dapat digunakan pada berbagai platform

6. Path : Sebuah aplikasi jejaring sosia pada telepon pintar yang memungkinkan penggunanya utk berbagi gambar dan juga pesan

Menurut Kemeterian Koperasi dan Usaha Kecil dan Menengah Republik indonesia yang dikutip dari https://www.ukmindonesia.id menerangkan ada 7 hal yang UKM perlu paham untuk tingkatkan akses pasar adalah sebagai berikut :

a. Pahami nilai keunggulan produk /layanan kita

b. Targetkan segmentasi pasa yang sfesifik

c. Mengenal raga sumber pendapatan usaha

d. Kenali ragam jalur distribusi untuk memperluas pasar

e. Kelola hubungan pelanggan dengan baik

f. Memahami manajemen pemasaran melalui $4 \mathrm{P}$

g. Memanfatkan digital arketing secara optimal

\section{Pengembangan Usaha}

Pengertian pengembangan usaha ialah peran dan cara sistematis untuk mempersiapkan kemungkinan pertumbuhan yang potensial, bantuan dan juga pengawasan terhadap penerapan peluang pengembangan usaha namun tidak mencangkup keputusan mengenai strategi dan pelaksanaan kesempatan pengembangan usaha.

Pengembangan usaha yaitu semua usaha dalam membenahi implementasi kerja baik sekarang ataupun kemudian hari dengan cara menyampaikan informasi yang dapat mempengaruhi sikap juga kemampuan.

Pengembangan sebuah usaha merupakan tanggung jawab para pengusaha yang memerlukan pandangan yang maju, dukungan dan juga daya cipta. Umumnya, dalam mengembangkan usahanya para pengusaha dituntut untuk bisa melihat peluang yang orang lain tak bisa melihatnya, tak bisa mengambil peluang, mengawali dan menjalankan usahanya dengan baik. Dengan melakukan pengembangan usaha 
maka seorang pelaku usaha akan mengerahkan seluruh pikiran dan juga tenaga untuk bisa memperbaiki kinerja mereka dengan cara melakukan perluasan dan meningkatkan mutu dan jumlah produksi.

Menurut Sudjatmoko (2009:140) banyak pilihan strategi dalam membangun kemitraan bisnis, dan masing-masing pihak tentu punya cara dan gaya sendiri. Secara umum beberapa strategi tersebut, antara lain:

1. Membangun Jejaring Kerja bukan sekedar bertukar kartu nama dan berkenalan.

2. Jadilah pendengar yang baik.

3. Upayakan dalam 72 jam kita harus berusaha menjalin komunikasi dengan mereka agar mereka tidak melupakan kita begitu saja.

4. Bersikap sabar tetapi aktif dan proaktif dalam memberi.

5. Bersikap lebih cerdas dan selalu menyampaikan informasi yang akurat dan apa adanya.

6. Kesinambungan komunikasi.

7. Menjadi anggota komunitas tertentu seperti forum HIPKI, HISSPI, HIPMI, Komunitas Entrepreneur dan sebagainya untuk menambah relasi dan memperlus wawasan.

8. Peduli lingkungan.

9. Membangun citra diri sebagai wirausaha.

10. Masuk ke lingungan organisasi profesi.

\section{Penelitian Terdahulu}

1. Sutrisno, 2013, Pengaruh Kompetensi Pengelola UMKM, Peran Pendampingan dan Pengelolaan Manajemen Terhadap Jejaring Pasar UMKM di Kota Banjarmasin. Penelitian ini menggunakan teknik analisis kuantitatif dengan metode analisis regresi berganda dan jumlah sampel yang diteliti sebanyak 100 responden UMKM, kesimpulan dalam penelitian ini mengemukakan bahwa semua variabel bebas seperti pengaruh kompetensi penglola umkm, peran pendampingan dan pengelolaan manajemen berpengaruh signifikan baik secara simultan maupun parsial terhadap variabel terikat Jejaring Pasar UMKM di Kota Banjarmasin sedangkan variabel yang dominan adalah kompetensi pengelola UMKM. Persamaan dalam penelitian ini yaitu, sama membahas masalah manajemen, sama sebagian variabel yang diteliti. Perbedaan dalam penelitian ini adalah berbeda terhadap obyek dan kondisi lingkungan penelitian, populasi dan sampel, penekanan masalah serta teknik analisis data peneliti terdahulu regresi berganda peneliti sekarang menggunakan smartpls.

2. Eka Dwi Puji Astuti, 2015, Pengaruh Kompetensi SDM, Pola Pendampingan Pemerintah dan Fungsi Manajerial Terhadap Pengembangan Pasar UKM di Kabupaten Banjar. Penelitian ini menggunakan teknik analisis kuantitatif dengan metode analisis regresi berganda dan jumlah sampel yang diteliti sebanyak 63 orang responden perlu UKM yanga da di Kabupaten Banjar Martapura dan kesimpulan dalam penelitian ini mengemukakan bahwa semua variabel bebas seperti kompetensi SDM, pola pendampingan pemerintah dan fungsi manajerial berpengaruh signifikan baik secara simultan maupun parsial terhadap variabel terikat terhadap Pengembangan Pasar UKM di Kabupaten Banjar dan variabel dominannya adalah kompetensi SDM. Persamaan dalam penelitian ini yaitu, sama membahas masalah MSDM dan sama dalam teknik analisis. Perbedaan dalam penelitian ini adalah berbeda terhadap obyek dan kondisi lingkungan penelitian serta penekanan masalah.

3. Wulandari, 2012 Pengaruh Kompetensi SDM, Kemampuan manajerial dan Peran Pendampingan Pemerintah Terhadap jejaring pasar dan Pengembangan Usaha UKM di Kabupaten Sleman Yogyakarta. Penelitian ini menggunakan teknik analisis kuantitatif dengan metode analisis jalur dan jumlah sampel yang diteliti sebanyak 75 orang responden UKM dan hasil penelitian ini mengemukakan bahwa semua variabel bebas seperti kemampuan manajerial, peran pendampingan pemerintah dan Jejaring pasar secara parsial berpengaruh signifikan baik secara langsung dan tidak langsung terhadap terhadap pengembangan usaha UKM di Kabupaten Sleman Yogyakarta.. Persamaan dalam penelitian ini yaitu, sama membahas masalah MSDM dan sama dalam teknik analisis. Perbedaan dalam penelitian ini adalah berbeda terhadap obyek dan kondisi lingkungan penelitian serta penekanan masalah.

\section{Motode Penelitian \\ Lokasi Penelitian}


Penelitian akan dilaksanakan pada Usaha Kecil Menengah di Kabupaten Balangan Provinsi Kalimantan Selatan.

\section{Populasi dan Sampel Populasi}

Arikunto, (2010:102) populasi adalah keseluruhan subyek penelitian. Populasi dari penelitian ini adalah pengelola UKM yang ada di Kabupaten Balangan, berdasarkan hal itu, maka dalam penelitian ini ditentukan jumlah populasi penelitiannya adalah sebanyak 5.124 UKM dari Sembilan sector Usaha UMKM yang ada di Kabupaten Bulungan.

\section{Sampel}

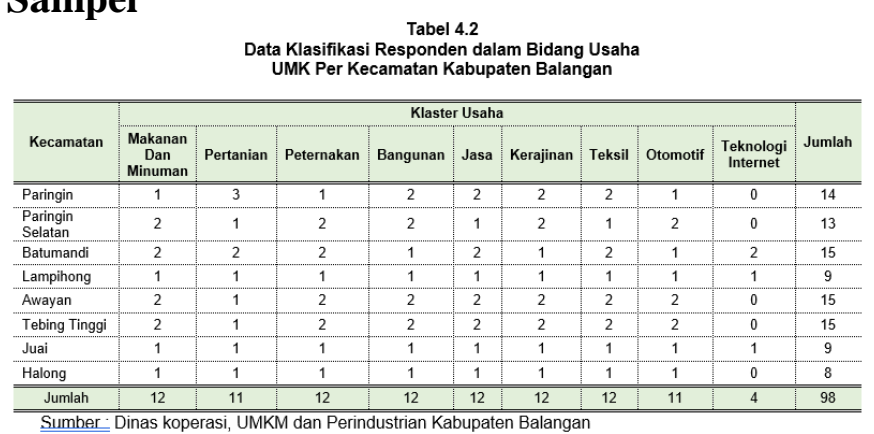

\section{Teknik Pengumpulan Data}

Teknik ini dimasudkan untuk mengetahui tinggi rendahnya skor jawaban respon terhadap pertanyaan yang diajukan. Untuk menentukan skor jawaban digunakan skala likert, yaitu yang digunakan untuk mengukur sikap, pendapatan, dan persepsi seseorang atau sekelompok orang tentang fenomena sosial. Jawaban instrumen yang menggunakan skala likert, yaitu berupa:

a. Sangat setuju

b. Setuju

c. Absen / Tidak memberikan pendapat

d. Tidak Setuju

e. Sangat tidak setuju

Untuk mengetahui tinggi rendahnya jawaban responden terhadap pertanyaan yang diajukan, maka digunakan teknik jenjang lima, maksudnya skor untuk setiap jawaban antara 1-5. Setiap responden dapat melihat salah satu dari lima alternatif jawaban yang tersusun berdasarkan bobot jawaban yang telah diklasifikasikan Untuk mengetahui hasil tanggapan responden terhadap variabel-variabel penelitian, maka digunakan skala likert untuk mengetahui pengukuran dan interprestasi data. Adapun penetapan akan skala likert dibagi dalam lima skor sebagai berikut ini untuk jawaban a nilai skor 5 , untuk jawaban $b$ nilai skor 4, untuk jawaban c nilai skor 3 , untuk jawaban d nilai skor 2 dan untuk jawaban e nilai skor 1 Hal ini dimaksudkan untuk memberi kebebasan responden dalam menilai suatu pertanyaan sesuai keyakinannya. Skor responden tersebut menggambarkan sikap responden yang sangat mendukung sesuai dengan pertanyaan yang diajukan mempunyai skor mendekati 5 atau sangat menolak sesuai dengan pertanyaan yang diberikan mempunyai skor 1 . Susunan kategori selanjutnya digunakan untuk mendiskripsikan tiap-tiap indikator dan variabel ke dalam bentuk tabel frekwensi.

\section{Teknik Analisis Data}

Dalam penelitian ini teknik pengolahan data yang akan dilakukan oleh penulis adalah dengan menggunakan kuantitatif yakni analisis bertujuan untuk membuat diskripsi, gambaran atau lukisan secara sistematis, faktual dan akurat mengenai fakta-fakta, sifat-sifat serta hubungan antar fenomena yang diselidiki secara terperinci untuk menghasilkan rekomendasi untuk keperluan di masa yang akan datang. Teknik analisis data dalam penelitian ini terbagi menjadi dua yang dapat dijelaskan dibawah :

\section{Analisis Deskriptif}

Analisis deskriptif adalah statistik yang digunakan untuk menganalisa data dengan cara mendeskripsikan atau menggambarkan data yang telah terkumpul sebagaimana adanya tanpa bermaksud membuat kesimpulan yang berlaku untuk digeneralisasikan. Statistik deskriptif dalam penelitian ini antara lain: penyiapan data dalam bentuk tabel, grafik, perhitungan median, mean, standar deviasi, perhitungan persentase, dan TCR (Sekaran, 2013:77). Data tersebut berasal dari jawaban yang diberikan oleh responden atas itemitem yang terdapat dalam kuesioner. Selanjutnya peneliti akan mengolah data kemudian diberi penjelasan.

Dalam Riduwan (2011:68) untuk mengetahui Kriteria interpretasi skor untuk Tingkat Capaian Responden (TCR) adalah sebagai berikut:

$$
\mathrm{TCR}=\frac{\text { Rata-rata skor }}{5} \times 100 \%
$$


Tabel 4.3

Tingkat Capaian Responden

\begin{tabular}{c|c}
\hline \hline Kreteria jawaban & Rentang Nilai \% \\
\hline Sangat Setuju & $81-100$ \\
Setuju & $61-80$ \\
\hline Ragu-Ragu/Absen & $41-60$ \\
\hline Tidak Setuju & $21-40$ \\
\hline Sangat Tidak Setuju & $0-20$ \\
\hline \hline
\end{tabular}

Sumber : Riduwan (2011)

\section{Analisis Data}

Menurut Ghozali (2015:98) sesuai dengan hipotesis yang telah dirumuskan, maka dalam penelitian ini analisis data statistik inferensial diukur dengan menggunakan software SmartPLS mulai dari pengukuran model (outer model), struktur model (inner model) dan pengujian hipotesis. PLS, merupakan pendekatan alternatif yang bergeser dari pendekatan Structural Equation Modeling (SEM) berbasis kovarian menjadi berbasis varian. SEM yang berbasis kovarian umumnya menguji kausalitas/teori sedangkan PLS lebih bersifat predictive model. PLS merupakan metode analisis yang powerfull, tidak harus memenuhi persyaratan asumsi normalitas data dan ukuran sampel tidak harus besar. PLS selain dapat digunakan sebagai konfirmasi teori juga dapat digunakan untuk membangun hubungan yang belum ada landasan teorinya atau untuk pengujian proposisi. Langkahlangkah pengujian yang dilakukan dalam penelitian ini adalah sebagai berikut:

(1) Evaluasi Measurement Model

Terdapat tiga macam pengujian yang dilakukan untuk mengevaluasi measurement model.

Jenis-jenis pengujian tersebut adalah:

a. Uji Individual Item Reliability

Pengujian ini dilakukan untuk melihat indikator mana yang baik digunakan untuk mengukur masing-masing variabel dengan kata lain untuk melihat reliabilitas dari setiap indikator. Nilai factor loding yang tinggi menunjukkan bahwa indikator tersebut memang menjelaskan variabel yang diukurnya. Indikator yang memiliki nilai factor loading antara 0.5-0.6 dapat diterima dan sebaliknya jika dibawah nilai tersebut akan dihilangkan dalam model saat melakukan pengujian ini.

b. Uji Internal Consistency
Pengujian ini dilakukan untuk menguji reliabilitas sekumpulan indikator dalam mengukur variabel yang diukurnya. Nilai yang dilihat adalah nilai composite reliability dan cronbach's alphayang diperoleh dari hasil estimasi SmartPLS. Nilai yang dikomendasikan adalah $>0.60$.

c. Uji Discriminant Validity

Pengujian ini dilakukan untuk melihat seberapa besar perbedaan antar variabel. Nilai yang dilihat dalam pengujian ini adalah nilai average variance extracted (AVE) yang diperoleh sebagai hasil estimasi dimana nilainya harus $>0,50$. Syarat berikutnya yang juga harus dipenuhi adalah nilai akar kuadrat dari AVE setiap variabel, harus lebih besar daripada nilai korelasi dengan variabel lainnya.

(2) Evaluasi Structural Model

Evaluasi Structural Model dengan menggunakan $\mathrm{R}$ square. Perubahan nilai $\mathrm{R}$ square dapat digunakan untuk menilai pengaruh variabel laten independen tertentu terhadap variabel laten dependen berdasarkan model penelitian. Secara umum nilai $\mathrm{R}$ square adalah $0.75, \quad 0.50, \quad$ dan 0.25 yang diinterpretasikan sebagai substansial, moderat, dan lemah

(3) Analisis Pengaruh Langsung

Ukuran signifikansi dapat menggunakan perbandingan nilai t-tabel dan t-statistic. Hipotesis diterima apabila t- statistic lebih tinggi dibandingkan nilai $t$ tabel atau dapat juga dengan membandingkan $\mathrm{p}$-valu dengan nilai $\alpha$ yang dipergunakan. Hipotesis dapat diterima jika nilai t-statistic > t tabel atau p-value < 0,05 .

(4) Analisis Pengaruh Tidak Langsung (Mediasi)

Efek mediasi menunjukkan hubungan antara variabel independen dan dependen melalui variabel penghubung atau mediasi. Pengaruh variabel terhadap variabel dependen tidak secara langsung terjadi tetapi melalui proses transformasi yang diwakili oleh variabel mediasi. Peranan variabel sebagai mediator terjadi apabila variasi pada variabel independen mampu menjelaskan secara signifikan variasi dalam variabel mediator, variasi pada variabel mediator mampu menjelaskan secara signifikan variasi dalam variabel dependen, dan ketika variabel mediator dikontrol, hubungan antara 
variabel independen dan variabel dependen tidak atau signifikan. Penetuan variabel intervening tergantung pada bentuk teoritiknya, misalnya pada model $\mathrm{A} \rightarrow \mathrm{B} \rightarrow \mathrm{C}$ dimana jelas hubungan $\mathrm{A} \rightarrow \mathrm{C}$ tidak langsung harus melalui $\mathrm{B}$, maka jika A ke B signifikan dan B ke C juga signifikan, maka $B$ adalah intervening dan hubungan A ke B tidak langsung melewati B. Untuk mengetahui apakah ada mediasi sempurna atau parsial dilakukan dengan melihat apakah koefisien c signifikan secara statistik. Perfect/complete mediation atau mediasi sempurna terjadi bila variabel independen tidak mempengaruhi dependen ketika mediator dikontrol. Jika koefisien c1 secara statistik signifikan dan terdapat mediasi yang signifikan juga, maka disebut mediasi parsial.

Pengujian efek mediasi dapat dilakukan dengan menghitung variance accounted for (VAF) dengan rumus pengaruh tidak langsung (indirect effect) / pengaruh total (total effect). Dimana pengaruh total adalah pengaruh langsung ditambah pengaruh tidak langsung. Jadi VAF merupakan ukuran seberapa besar variabel pemediasi mampu menyerap pengaruh langsung yang sebelumnya signifikan dari model tanpa pemediasi

$$
\mathrm{VAF}=\frac{\text { Pengaruh tidak langsung }}{\text { Pengarh langsung }+ \text { pengaruh }}
$$

Untuk hipotesis diatas, nilai VAF dihitung dengan cara (jalur a $\mathrm{x}$ jalur $\mathrm{b}$ ) / (jalur $\mathrm{a} \mathrm{x}$ jalur $\mathrm{b}$ + jalur c).

\section{Analisis Dan Pembahasan}

Teknik pengolahan data dengan menggunakan Partial Least Square (PLS) memerlukan dua tahap menilai Fit Model dari sebuah model penelitian (Ghozali, 2006). Tahaptahap tersebut adalah sebagai berikut:

\section{Menilai Outer Model atau Measurement Model}

Evaluasi model SEM-PLS pada model pengukuran (outer model) dievaluasi dengan melihat validitas dan reabilitas. Untuk melakukan uji ini, langkah pertama yang harus dilakukan setelah semua data telah dimasukkan ke aplikasi smartpls adalah memilih menu calculate setelah itu pilih PLS algorithm lalu pilih start caculation, setelah itu akan muncul data-data dengan beberapa pilihan menu dibagian bawah, pilih menu construct reliability and validity, maka akan tampil data yang diinginkan. Berikut penjabaran hasil uji reliability.

\section{Uji Validitas}

Menurut (Syarah Widyaningtyas, Triastuti Wuryandari \& Moch. Abdul Mukid, 2016) Uji validitas dimaksudkan untuk mengukur sejauh mana ketepatan dan kecermatan suatu alat ukur dalam melakukan fungsi alat ukurnya atau memberikan hasil ukur yang sesuai dengan menghitung korelasi antar masing- masing pernyataan dengan skor total. Pada penelitian ini, uji validitas pengukuran terdiri dari validitas konvergen dan validitas diskriminan.

\section{a. Uji Convergent Validity}

Validitas konvergen (Convergent Validity) bertujuan untuk mengetahui validitas setiap hubungan antara indikator dengan konstruk atau variabel latennya. Validitas konvergen dari model pengukuran dengan refleksif indikator dinilai berdasarkan korelasi antara skor item atau component score dengan skor variabel laten atau construct score yang diestimasi dengan program PLS.

Berikut adalah gambar hasil kalkulasi model SEM PLS, selanjutnya dilihat nilai loading faktor indikator-indikator pada setiap variabel.

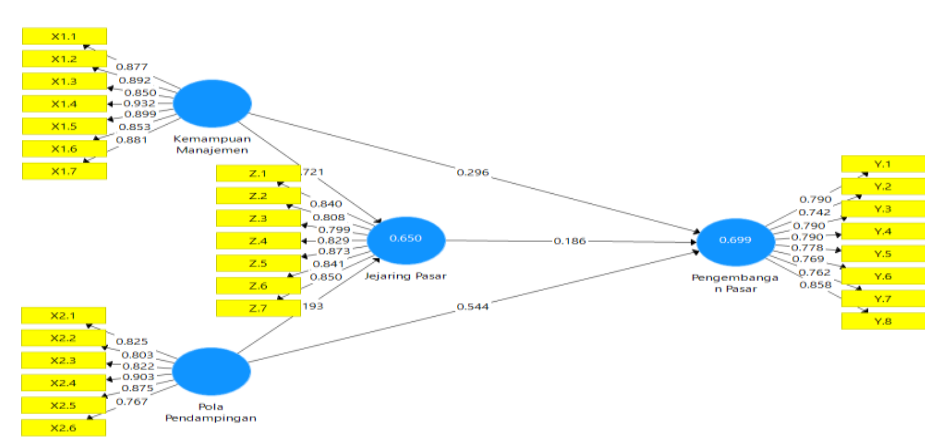

Gambar 5.1 Model PLS 1

Sumber Lampiran 3

1. Variabel X1 (Kemampuan Manajemen) Pada Tabel 5.13 indikator Kemampuan Manajemen diukur dengan cutoff $>0,7$, maka dapat dilakukan evaluasi sebagai berikut :

Tabel 5.13 


\section{Output X1 (Kemampuan Manajemen)}

\begin{tabular}{c|c|r|c}
\hline \hline Variabel & $\begin{array}{c}\text { Item } \\
\text { Pertanyaan }\end{array}$ & $\begin{array}{c}\text { Loading } \\
\text { Factor }\end{array}$ & Keterangan \\
\hline \hline & $\mathrm{X} 1.1$ & $\mathbf{0 , 8 7 7}$ & VALID \\
Xemampuan & $\mathrm{X} 1.2$ & $\mathbf{0 , 8 9 2}$ & VALID \\
$\begin{array}{c}\text { Manajemen } \\
(\mathrm{X} 1)\end{array}$ & $\mathrm{X} 1.4$ & $\mathbf{0 , 8 5 0}$ & VALID \\
& $\mathrm{X} 1.5$ & $\mathbf{0 , 9 3 2}$ & VALID \\
& $\mathrm{X} 1.6$ & $\mathbf{0 , 8 9 9}$ & VALID \\
& $\mathrm{X} 1.7$ & $\mathbf{0 , 8 5 3}$ & VALID \\
\hline \hline
\end{tabular}

Sumber Lampiran 3

Dari hasil pengolahan data dengan PLS yang terlihat pada Tabel 5.13 di atas, dapat dievaluasi bahwa seluruh indikator pada variabel Kemampuan Manajemen dalam penelitian ini memiliki nilai loading yang lebih besar dari 0,70. Hal ini menunjukkan bahwa indikator variabel yang memiliki nilai loading lebih besar dari 0,70 memiliki tingkat validitas yang tinggi, sehingga memenuhi convergent validity.

2. Variabe X2 (Pola Pendampingan)

Pada Tabel 5.16 semua indikator Pola Pendampingan tidak ada yang mempunyai nilai loading faktor di bawah 0,7 sehingga semua indikator tetap digunakan.

\section{Tabel 5.14}

Output X2 (Pola Pendampingan)

\begin{tabular}{c:c:c:c}
\hline \hline Variabel & $\begin{array}{c}\text { Item } \\
\text { Pertanyaan }\end{array}$ & $\begin{array}{c}\text { Loading } \\
\text { Factor }\end{array}$ & Keterangan \\
\hline & $\mathrm{X} 2.1$ & $\mathbf{0 , 8 2 5}$ & VALID \\
$\begin{array}{c}\text { Pola } \\
\text { Pendampingan }\end{array}$ & $\mathrm{X} 2.2$ & $\mathbf{0 , 8 0 3}$ & VALID \\
$(\mathrm{X} 2)$ & $\mathrm{X} 2.3$ & $\mathbf{0 , 8 2 2}$ & VALID \\
& $\mathrm{X} 2.5$ & $\mathbf{0 , 9 0 3}$ & VALID \\
& $\mathrm{X} 2.6$ & $\mathbf{0 , 8 7 5}$ & VALID \\
\hline \hline
\end{tabular}

\section{Sumber Lampiran 3}

Dari hasil pengolahan data dengan PLS yang terlihat pada Tabel 5.14 di atas, dapat dilihat bahwa seluruh indikator pada variabel Pola Pendampingan dalam penelitian ini memiliki nilai loading yang lebih besar dari 0,70. Hal ini menunjukkan bahwa indikator variabel yang memiliki nilai loading lebih besar dari 0,70 memiliki tingkat validitas yang tinggi, sehingga memenuhi convergent validity.

3. Variabel Z (Jejaring Pasar)
Pada Tabel 5.15 semua indikator Jejaring Pasar tidak ada yang mempunyai nilai loading faktor di bawah 0,7 sehingga semua indikator tetap digunakan.

Tabel 5.15

Output Y (Jejaring Pasar)

\begin{tabular}{c|c|c|l}
\hline \hline Variabel & $\begin{array}{c}\text { Item } \\
\text { Pertanyaan }\end{array}$ & $\begin{array}{c}\text { Loading } \\
\text { Factor }\end{array}$ & Keterangan \\
\hline \hline \multirow{4}{*}{ Jejaring } & $\mathrm{Z} .1$ & $\mathbf{0 , 8 4 0}$ & VALID \\
\hline Pasar $(\mathrm{Z})$ & $\mathrm{Z} .2$ & $\mathbf{0 , 8 0 8}$ & VALID \\
& $\mathrm{Z} .3$ & $\mathbf{0 , 7 9 9}$ & VALID \\
& $\mathrm{Z} .4$ & $\mathbf{0 , 8 2 9}$ & VALID \\
& $\mathrm{Z} .5$ & $\mathbf{0 , 8 7 3}$ & VALID \\
& $\mathrm{Z} .6$ & $\mathbf{0 , 8 4 1}$ & VALID \\
& $\mathrm{Z} .7$ & $\mathbf{0 , 8 5 0}$ & VALID \\
\hline
\end{tabular}

Sumber Lampiran 3

Dari hasil pengolahan data dengan PLS yang terlihat pada Tabel 5.15 di atas, dapat dilihat bahwa seluruh indikator pada variabel Jejaring Pasar dalam penelitian ini memiliki nilai loading yang lebih besar dari 0,70. Hal ini menunjukkan bahwa indikator variabel yang memiliki nilai loading lebih besar dari 0,70 memiliki tingkat validitas yang tinggi, sehingga memenuhi convergent validity

4. Variabel Y (Pengembangan Pasar)

Pada Tabel 5.16 semua indikator Pengembangan Pasar tidak ada yang mempunyai nilai loading faktor di bawah 0,7 sehingga semua indikator tetap digunakan.

Tabel 5.16

Output Y (Pengembangan Pasar)

\begin{tabular}{|c|c|c|c|}
\hline Variabel & $\begin{array}{c}\text { Item } \\
\text { Pertanyaan }\end{array}$ & $\begin{array}{c}\text { Loading } \\
\text { Factor }\end{array}$ & Keterangan \\
\hline Y.1 & $\mathbf{0 , 7 9 0}$ & VALID \\
\hline Y.2 & $\mathbf{0 , 7 4 2}$ & VALID \\
\hline Jejaring & Y.3 & $\mathbf{0 , 7 9 0}$ & VALID \\
\hline Pasar (Z) & Y.5 & $\mathbf{0 , 7 9 0}$ & VALID \\
\hline Y.6 & $\mathbf{0 , 7 7 8}$ & VALID \\
\hline Y.7 & $\mathbf{0 , 7 6 9}$ & VALID \\
\hline Y.8 & $\mathbf{0 , 7 6 2}$ & VALID \\
\hline
\end{tabular}

Sumber Lampiran 3

Dari hasil pengolahan data dengan PLS yang terlihat pada Tabel 5.16 di atas, dapat dilihat bahwa seluruh indikator pada 
variabel Pengembangan Pasar dalam penelitian ini memiliki nilai loading yang lebih besar dari 0,70. Hal ini menunjukkan bahwa indikator variabel yang memiliki nilai loading lebih besar dari 0,70 memiliki tingkat validitas yang tinggi, sehingga memenuhi convergent validity

\section{b. Validitas Diskriminan}

Discriminant validity yaitu pengujian validitas konstruk dengan memprediksi ukuran indikator dari masing-masing bloknya (Nur Ayu Setia Ningsih \& Sigit Hermawan, 2019). Jika nilai akar AVE >0,60, maka artinya validitas deskriminan tercapai (Novrian Dandi Pratama, Ahim Abdurahim \& Hafiez Sofyani, 2018).

\section{Tabel 5.17}

Nilai AVE

\begin{tabular}{l|c|c|}
\hline \multicolumn{1}{|c|}{ Variabel } & $\begin{array}{c}\text { Composit } \\
\mathbf{e} \\
\text { Reliabilit } \\
\mathbf{y}\end{array}$ & $\begin{array}{c}\text { Average } \\
\text { Variance } \\
\text { Extracted } \\
\text { (AVE) }\end{array}$ \\
\hline $\begin{array}{l}\text { Kemampuan } \\
\text { Manajemen }\end{array}$ & 0,962 & 0,781 \\
\hline $\begin{array}{l}\text { Pola } \\
\text { Pendampingan }\end{array}$ & 0,932 & 0,695 \\
\hline Jejaring Pasar & 0,941 & 0,697 \\
\hline $\begin{array}{l}\text { Pengembangan } \\
\text { Pasar }\end{array}$ & 0,928 & 0,617 \\
\hline
\end{tabular}

Sumber Lampiran 3

Berdasarkan tabel 5.17 dapat disimpulkan bahwa semua konstruk memenuhi kriteria reliable Hal ini ditunjukkan dengan nilai composite reliability Setiap Variabel Kemampuan Manajemen (0,962), Pola Pendampingan (0,932), Jejaring Pasar $(0,941)$, dan Pengembangan Pasar $(0,928)$ diatas 0,70 sebagaimana kriteria yang direkomendasikan. nilai AVE pada variabel Kemampuan Manajemen (0,781), Pola Pendampingan (0,695), Jejaring Pasar $(0,676)$, dan Pengembangan Pasar $(0,697)$ bernilai > 0,50. Sehingga dapat dikatakan bahwa model pengukuran tersebut telah valid secara descriminant validity.

\begin{tabular}{|c|c|c|c|c|}
\hline \multicolumn{5}{|c|}{ Tabel 5.18} \\
\hline & $\begin{array}{c}\text { Jejaring } \\
\text { Pasar }\end{array}$ & $\begin{array}{l}\text { Kemampuan } \\
\text { Manajemen }\end{array}$ & $\begin{array}{c}\text { Pengembangan } \\
\text { Pasar }\end{array}$ & $\begin{array}{c}\text { Pola } \\
\text { Pendampingan }\end{array}$ \\
\hline $\mathbf{X 1 . 1}$ & 0,717 & 0,877 & 0,563 & 0,334 \\
\hline$\times 1.2$ & 0,671 & 0,892 & 0,508 & 0.195 \\
\hline $\mathbf{X 1 . 3}$ & 0,701 & 0,850 & 0,493 & 0,243 \\
\hline X1.4 & 0,714 & 0,932 & 0,583 & 0,317 \\
\hline$\times 1.5$ & 0,717 & 0,899 & 0,585 & 0,330 \\
\hline $\mathbf{X 1 . 6}$ & 0,608 & 0,853 & 0,467 & 0,216 \\
\hline $\mathbf{X 1 . 7}$ & 0,720 & 0,881 & 0,634 & 0,398 \\
\hline$\times 2.1$ & 0,422 & 0,243 & 0,673 & 0,825 \\
\hline$\times 2.2$ & 0,329 & 0,137 & 0,567 & 0,803 \\
\hline$\times 2.3$ & 0,311 & 0,242 & 0,563 & 0,822 \\
\hline$x 2.4$ & 0,402 & 0,349 & 0,673 & 0,903 \\
\hline$\times 2.5$ & 0,344 & 0,353 & 0,620 & 0,875 \\
\hline$\times 2.6$ & 0,343 & 0,338 & 0,490 & 0,767 \\
\hline $\mathrm{Z} .1$ & 0,840 & 0,715 & 0,554 & 0,327 \\
\hline $\mathrm{Z.2}$ & 0,808 & 0,640 & 0,445 & 0,283 \\
\hline $\mathrm{Z} 3$ & 0,799 & 0,625 & 0,638 & 0,347 \\
\hline $\mathrm{Z.4}$ & 0,829 & 0,607 & 0,512 & 0,410 \\
\hline $\mathrm{Z.5}$ & 0,873 & 0,638 & 0,574 & 0,400 \\
\hline Z.6 & 0,841 & 0,661 & 0,571 & 0,420 \\
\hline Z.7 & 0.850 & 0,696 & 0,511 & 0,336 \\
\hline Y.1 & 0,495 & 0,397 & 0,790 & 0,558 \\
\hline Y.2 & 0,672 & 0,660 & 0,742 & 0,505 \\
\hline Y.3 & 0,632 & 0,736 & 0,790 & 0,607 \\
\hline Y.4 & 0,463 & 0,470 & 0,790 & 0,551 \\
\hline Y.5 & 0,428 & 0,348 & 0,778 & 0,558 \\
\hline Y.6 & 0,456 & 0,396 & 0,769 & 0,544 \\
\hline Y.7 & 0,405 & 0,327 & 0,762 & 0,574 \\
\hline Y.8 & 0,493 & 0,466 & 0,858 & 0,635 \\
\hline
\end{tabular}

Pada tabel 5.18 cross loading dapat di jelaskan yaitu variabel laten dengan nilai yang lebih besar dibanding nilai variabel laten lainnya Kemampuan Manajemen yang terdapat 7 indikator dengan nilai tertinggi 0,877, 0,892, 0,850,0,932, 0,899, 0,853 dan 0,881 , variabel Pola Pendampingan yang terdapat 6 indikator dengan nilai tertinggi $0,825,0,803,0,822,0,903,0,875$ dan 0,767 , variabel Jejaring Pasar yang terdapat 7 indikator dengan nilai tertinggi $0,840,0,808$, $0,799,0,829$. 0,873, 0,841 dan 0,850, variabel Pengembangan Pasar yang terdapat 8 indikator dengan nilai tertinggi $0,790,0,742$, 0,790, 0,778, 0,778, 0,762 dan 0,762 . Dari hasil estimasi cros loading pada tabel 5.9 menunjukkan bahwa nilai cross loading untuk setiap indikator dari masing-masing variabel laten lebih besar dibanding nilai variabel laten lainnya dan memiliki nilai $>0,7$. Hal ini berarti bahwa setiap variabel laten sudah memiliki discriminant validity yang baik, dimana beberapa variabel laten memiliki pengukur yang berkorelasi tinggi dengan konstruk lainnya.

\section{Uji Reliabilitas}

Menurut (Jonathan Sarwono, 2014) reliabilitas merupakan ukuran konsistensi internal indikator-indikator suatu konstruk yang menunjukkan derajat sejauh mana setiap indikator tersebut menunjukkan sebuah konstruk laten yang umum . 
Menurut (Dionysia Kowanda, 2016) syarat reliabilitas merupakan ukuran suatu kestabilan dan konsistensi dari hasil (data) dalam waktu yang berbeda. Untuk menguji reliabilitas konstruk dalam penelitian digunakan nilai composite reliability. Suatu variabel dikatakan memenuhi reliabilitas konstruk jika memiliki nilai composite reliability > 0,7 (Billy J. Maspaitella et al, 2018) dan nilai crobanch apha yang bernilai > 0,7 memiliki tingkat reabilitas yang baik bagi sebuah variabel (Assegaff, 2015). Nilai composite reliability masing-masing indikator dapat dilihat pada tabel 5.19 berikut

\begin{tabular}{|c|c|c|c|c|}
\hline & \multicolumn{3}{|c|}{ Table 5.19} & \\
\hline Variabel & $\begin{array}{c}\text { Cronbach's } \\
\text { Alpha }\end{array}$ & rho_A & $\begin{array}{l}\text { Composite } \\
\text { Reliability }\end{array}$ & Keterangan \\
\hline Kemampuan Manajemen & 0,953 & 0,956 & 0,962 & Reliabel \\
\hline Pola Pendampingan & 0,912 & 0,919 & 0,932 & Reliabel \\
\hline Jejaring Pasar & 0,927 & 0,928 & 0,941 & Reliabel \\
\hline Pengembangan Pasar & 0,911 & 0,915 & 0,928 & Reliabel \\
\hline \multicolumn{5}{|c|}{ Sumber Lampiran 3} \\
\hline Pada & tabel & .19 & reliabil & daps \\
\hline dijelaskan & yaitu & varia & & nampus \\
\hline
\end{tabular}
Manajemen dengan Cronbanch's Alpa 0,953 sedangkan composit reliability 0,956 maka dinyatakan reliable, variabel Pola Pendampingan dengan Cronbanch's Alpa 0,912 sedangkan composit reliability 0,932 maka dinyatakan reliable, variabel Jejaring Pasar dengan Cronbanch's Alpa 0,927 sedangkan composit reliability 0,941 maka dinyatakan reliable, variabel Pengembangan Pasar dengan Cronbanch's Alpa 0,911 sedangkan composit reliability 0,928 maka dinyatakan reliable.

Pada tabel 5.19 dapat dilihat hasil analisis uji reliabilitas menggunakan alat bantu SmartPLS yang menyatakan bahwa semua nilai composit reliability setiap lebih besar 0,7 yang berarti semua variabel telah reliable dan telah memenuhi kriteria pengujian. Selanjutnya nilai cronbanch's alpa juga menunjukkan bahwa semua nilai cronbanch's alpa lebih dari 0,6 dan hal ini menunjukkan tingkat reliabilitas variabel juga telah memenuhi kriteria.

Jika model pengukuran valid dan reliabel maka dapat dilakukan tahap selanjutnya yaitu evaluasi model structural dan jika tidak, maka harus kembali mengkonstruksi diagram jalur.

\section{Pengujian Model Struktur (Inner Model)}

Pengujian inner model atau model struktural dilakukan untuk melihat hubungan antara konstruk, nilai signifikansi dan R-square dari model penelitian. Model struktural dievaluasi dengan menggunakan R-square untuk konstruk dependen uji t serta signifikansi dari koefisien parameter jalur struktural.

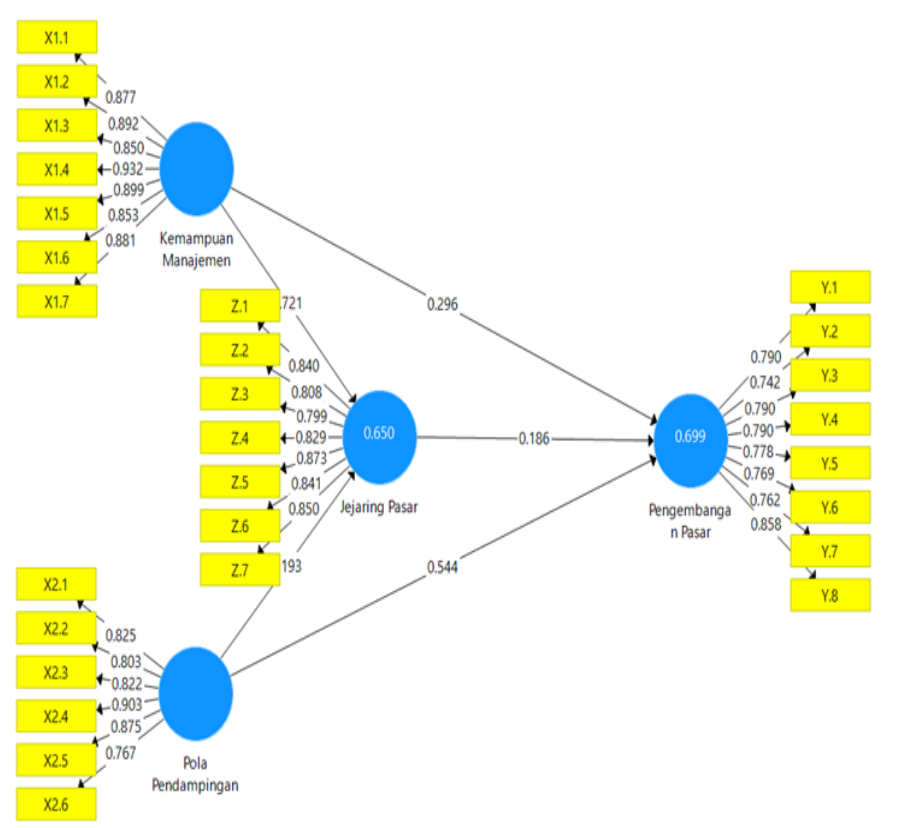

Gambar 5.1 Model Struktural Sumber Lampiran 3

1. Uji Kebaikan Model (Goodness of Fit)

Dalam menilai model dengan PLS dimulai dengan melihat R-square untuk setiap variabel laten dependen. Tabel 5.20 merupakan hasil estimasi R-square dengan menggunakan SmartPLS.

Tabel 5.20

\section{R-Square}

\begin{tabular}{l|l}
\hline \hline Variabel & R-Square \\
\hline \hline Jejaring Pasar (Z) & 0,650 \\
\hline Pengembangan Pasar (Y) & 0,699 \\
\hline \hline
\end{tabular}

Sumber: Lampiran 3 Uji Smart PLS

Pada prinsipnya penelitian ini menggunakan 2 buah variabel yang dipengaruhi oleh variabel lainnya yaitu variabel Jejaring Pasar yang dipengaruhi oleh kemampuan Manajemen, Pola Pendampingan dan variabel Pengembangan Pasar yang dipengaruhi oleh Jejaring Pasar.

Penilaian goodness of fit diketahui dari nilai Q-Square. Nilai Q-Square memiliki arti yang sama dengan coefficient determination (R-Square) pada analisis regresi, dimana semakin tinggi Q- 
Square, maka model dapat dikatakan semakin baik atau semakin fit dengan data.

Tabel 5. 21

Hasil Pengujian Q-square

\begin{tabular}{l|l|l|r}
\hline \hline & SSO & SSE & $\begin{array}{l}\mathbf{Q}^{2}(=1- \\
\text { SSE/SSO) }\end{array}$ \\
\hline \hline Jejaring Pasar & 686,000 & 379,555 & 0,447 \\
\hline $\begin{array}{l}\text { Kemampuan } \\
\text { Manajemen }\end{array}$ & 686,000 & 686,000 & \\
\hline $\begin{array}{l}\text { Pengembangan } \\
\text { Pasar }\end{array}$ & 784,000 & 461,061 & 0,412 \\
$\begin{array}{l}\text { Pola } \\
\text { Pendampingan }\end{array}$ & 588,000 & 588,000 & \\
\hline \hline
\end{tabular}

Sumber: Lampiran 5 Uji Smart PLS

Berdasarkan tabel di atas, diketahui hasil penjumlahan nilai QSquare pada kedua variabel endogen adalah sebesar 0,859. Hasil tersebut berarti besarnya keragaman data yang dijelaskan oleh model penelitian ini adalah sebesar $85,9 \%$. Sedangkan persentase yang tersisa sebesar $14,1 \%$ dijelaskan oleh faktor lain yang berada di luar model penelitian ini. Dengan demikian, model penelitian ini dinyatakan memenuhi syarat kebaikan (model fit). Hal ini menunjukkan besarnya keragaman data memiliki pengaruh yang sangat kuat terhadap model penelitian ini.

\section{Pengujian Hipotesis}

Signifikansi parameter yang diestimasi memberikan informasi yang sangat berguna mengenai hubungan antara variabel-variabel penelitian. Dasar yang digunakan dalam menguji hipotesis adalah nilai yang terdapat pada output result for inner weight.

\section{Pengujian Hipotesis Pengaruh Langsung}

Dasar pengujian hipotesis dalam penelitian ini adalah nilai yang terdapat pada output result for inner weight. Hasil output estimasi untuk pengujian model struktural dapat dilihat pada table 5.22 berikut

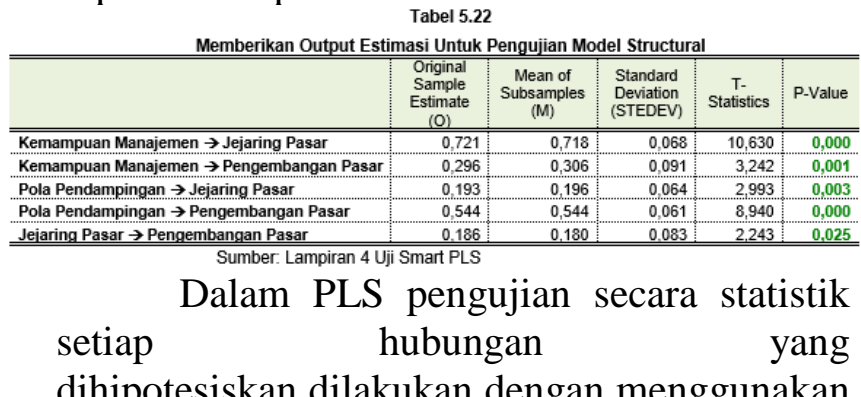

simulasi.

Dalam

hal

ini dilakukan metode bootstraping terhadap sampel. Pengujian dengan bootstraping juga dimaksudkan untuk meminimalkan masalah ketidaknormalan data penelitian. Hasil pengujian dengan bootstrapping dari analisis PLS adalah sebagai berikut:

a. Pengaruh Kemampuan Manajemen

Terhadap Jejaring Pasar

Berdasarkan hasil pengujian pada tabel menunjukkan bahwa untuk variabel Kemampuan Manajemen diperoleh nilai koefisien sebesar 0,721 nilai p-value sebesar 0,000 . Nilai tersebut lebih kecil dari nilai alpha (5\%). Artinya bahwa variabel Kemampuan Manajemen berpengaruh dan signifikan terhadap Jejaring Pasar, maka hipotesis 1 diterima.

b. Pengaruh Kemampuan Manajemen Terhadap Pengembangan Pasar

Berdasarkan hasil pengujian pada tabel menunjukkan bahwa untuk variabel Kemampuan Manajemen diperoleh nilai koefisien sebesar 0.296 nilai p-value 0,001. Nilai tersebut lebih kecil dari nilai alpha (5\%). Artinya bahwa variabel Kemampuan Manajemen berpengaruh positif dan signifikan terhadap Pengembangan Pasar, maka hipotesis 4 diterima.

c. Pengaruh Pola Pendampingan Terhadap Jejaring Pasar

Berdasarkan hasil pengujian pada tabel menunjukkan bahwa untuk variabel Pola Pendampingan diperoleh nilai koefisien sebesar 0,193 nilai p-value sebesar 0,003. Nilai tersebut lebih kecil dari nilai alpha (5\%). Artinya bahwa variabel Pola Pendampingan berpengaruh positif dan signifikan terhadap Jejaring Pasar, maka hipotesis 2 diterima.

d. Pengaruh Pola Pendampingan Terhadap Pengembangan Pasar

Berdasarkan hasil pengujian pada tabel menunjukkan bahwa untuk variabel Pola Pendampingan diperoleh nilai koefisien sebesar 0,544 nilai p-value sebesar 0,000. Nilai tersebut lebih kecil dari nilai alpha (5\%). Artinya bahwa variabel Pola Pendampingan berpengaruh positif dan signifikan terhadap Jejaring Pasar, maka hipotesis 2 diterima. 
e. Pengaruh Jejaring Pasar Terhadap Pengembangan Pasar

Berdasarkan hasil pengujian pada tabel menunjukkan bahwa untuk variabel Jejaring Pasar diperoleh nilai koefisien sebesar 0,025 nilai p-value 0,000 . Nilai tersebut lebih besar dari nilai alpha (5\%). Artinya bahwa variabel Jejaring Pasar berpengaruh positif dan signifikan terhadap Pengembangan Pasar, maka hipotesis 5 diterima.

\section{Pengujian Hipotesis Pengaruh Tidak Langsung}

Hasil pengujian hiotesis pengaruh tidak langsung melalui Jejaring Pasar sebagai variabel intervening dengan menggunakan program bantu Sobel test Calculator dapat disajikan pada tabel 5.23 berikut:

Tabel 5.23

Total Indirect Effects

\begin{tabular}{|c|c|c|c|c|c|}
\hline \multicolumn{6}{|c|}{ Total Indirect Effects } \\
\hline Variabel & $\begin{array}{c}\text { Original } \\
\text { Sample } \\
\text { Estimate (O) }\end{array}$ & $\begin{array}{c}\text { Mean of } \\
\text { Subsamples } \\
\text { (M) }\end{array}$ & $\begin{array}{l}\text { Standard } \\
\text { Deviation } \\
\text { (STEDEV) }\end{array}$ & $\begin{array}{c}\mathrm{T} \text { - } \\
\text { Statistics }\end{array}$ & $\begin{array}{c}\text { P. } \\
\text { Value }\end{array}$ \\
\hline $\begin{array}{l}\text { Kemampuan Manajemen } \rightarrow \text { Jejaring Pasar } \rightarrow \\
\text { Pengembangan Pasar }\end{array}$ & 0,134 & 0,127 & 0,059 & 2,273 & 0,023 \\
\hline $\begin{array}{l}\text { Pola Pendampingan } \rightarrow \text { Jejaring Pasar } \rightarrow \\
\text { Pengembangan Pasar }\end{array}$ & 0,036 & 0,036 & 0,023 & 1,569 & 0,117 \\
\hline
\end{tabular}

a. Pengaruh Kemampuan Manajemen Terhadap Pengembangan Pasar Melalui Jejaring Pasar

Kemampuan Manajemen berpengaruh signifikan terhadap Pengembangan Pasar pada melalui Jejaring Pasar sebagai variabel intervening Pengaruh Kemampuan Manajemen terhadap Pengembangan Pasar pada melalui Jejaring Pasar sebagai variabel intervening dengan ditunjukkan nilai tstatistic sebesar 2,273 di atas dari t tabel (1.998). Hal ini berarti Hipotesis 6 diterima. Berarti Kemampuan Manajemen secara tidak langsung melalui Jejaring Pasar sebagai variabel intervening berpengaruh signifikan terhadap Pengembangan Pasar pada yang berarti Kemampuan Manajemen mampu meningkatkan Pengembangan Pasar melalui Jejaring Pasar sebagai variabel intervening.

b. Pengaruh Pola Pendampingan Terhadap Pengembangan Pasar Melalui Jejaring Pasar

Pola Pendampingan tidak berpengaruh signifikan terhadap Pengembangan Pasar pada melalui Jejaring Pasar sebagai variabel intervening Pengaruh Pola Pendampingan terhadap Pengembangan
Pasar pada melalui Jejaring Pasar sebagai variabel intervening dengan ditunjukkan nilai tstatistic sebesar 1,569 yang lebih kecil dari $t$ tabel (1.998). Hal ini berarti Hipotesis 7 ditolak. Berarti Pola Pendampingan secara tidak langsung melalui Jejaring Pasar sebagai variabel intervening tidak berpengaruh signifikan terhadap Pengembangan Pasar pada yang berarti Pola Pendampingan belum kuat dalam meningkatkan Pengembangan Pasar melalui Jejaring Pasar sebagai variabel intervening.

\section{Pambahasan}

Pengaruh Kemampuan Manajemen terhadap Jejaring Pasar pada Usaha Kecil Dan Menengah Di Kabupaten Balangan

Berdasarkan hasil uji hipotesis, dapat disimpulkan bahwa Kemampuan Manajemen berpengaruh positif signifikan terhadap Jejaring Pasar pada Usaha Kecil Dan Menengah Di Kabupaten Balangan. Hasil ini menunjukkan bahwa Kebanyakan responden setuju tentang Kemampuan Manajemen dari UMKM yang dilakukan merupakan antara lain kurang memahami kinerja yang diharapkan dari posisinya sebagai seorang pimpinan kelompok kerja, profesionalisme dalam bekerja rendah, jalur komunikasi yang kurang baik, kurang memahami peran manajerial, tidak mempunyai keterampilan manajerial yang diperlukan untuk menghasilkan kinerja manajerial yang ditargetkan, kompetensi diri rendah, dan lemah dalam hal memotivasi atau menggerakkan orang-orang yang dipimpinnya yang terus semakin ditingkatkan pada operasional Usaha Kecil Dan Menengah Di Kabupaten Balangan dan akan berdampak terhadap perbaikan Jejaring Pasar. Sutrisno, 2013, dengan judul Pengaruh Kompetensi Pengelola UMKM, Peran Pendampingan dan Pengelolaan Manajemen Terhadap Jejaring Pasar UMKM di Kota Banjarmasin. Hasil penelitian ini mengemukakan bahwa semua variabel bebas seperti pengaruh kompetensi penglola UMKM, peran pendampingan dan pengelolaan manajemen berpengaruh signifikan baik secara parsial terhadap variabel terikat Jejaring Pasar UMKM di Kota Banjarmasin.

Kemampuan Manajemen dalam menaikkan jejaring pasar yang diinginkan disini adalah menunjukkan karakteristik pengetahuan 
dan keterampilan yang dimiliki atau dibutuhkan oleh setiap individu untuk meningkatkan jejaring pasar mereka dalam melakukan tugas dan tanggung jawab mereka secara efektif dan meningkatkan standar kualitas profesional dalam kegiatan operasional UMKM. Kemampuan manajemen ini menjelaskan apa yang dilakukan orang di tempat kerja pada berbagai tingkatan dan merinci standar masing-masing tingkatan, mengindentifikasi karakteristik, pengetahuan dan keterampilan yang diperlukan oleh individu yang memungkinkan menjalankan. Kemampuan manajemen dalam menaikkan jejaring pasar disini yang dituntut adalah kemampuan manajemen dalam manikkan sebuah sistem jual beli yang menghasilkan media komunikasi antar para pembeli dengan penjual dalam menaikkan jejaring pasar.

\section{Pengaruh Pola Pendampingan terhadap Jejaring Pasar pada Usaha Kecil Dan Menengah Di Kabupaten Balangan}

Berdasarkan hasil uji hipotesis, dapat disimpulkan bahwa Pola Pendampingan berpengaruh positif signifikan terhadap Jejaring Pasar pada Usaha Kecil Dan Menengah Di Kabupaten Balangan. Hasil ini menunjukkan bahwa kebanyakan respondent Usaha Kecil Dan Menengah Di Kabupaten Balangan setuju perlunya Pendamping bagi UMKM yang belum memiliki kemampuan dan teknik dalam berkomunikasi yang baik, Pendamping bagi UMKM belum mampu membuat progam kerja, Pendamping bagi UMKM yang belum menguasai dan menggunakan teknologi dalam bidang pekerjaan, Ketersediaan tenaga pendamping masih terbatas dibanding dengan wilayah kerjanya, pendamping bagi UMKM yang belum mampu memberikan informasi yang dibutuhkan dan masih banyaknya sikap dari tenaga pendamping yang tidak professional. Hasil ini sejalan dengan penelitian Sutrisno, 2013, dengan judul Pengaruh Kompetensi Pengelola UMKM, Peran Pendampingan dan Pengelolaan Manajemen Terhadap Jejaring Pasar UMKM di Kota Banjarmasin. Hasil penelitian ini mengemukakan bahwa semua variabel bebas seperti pengaruh kompetensi penglola UMKM, peran pendampingan dan pengelolaan manajemen berpengaruh signifikan baik secara parsial terhadap variabel terikat Jejaring Pasar UMKM di Kota Banjarmasin.
Gaya Pola Pendampingan merupakan hal penting yang harus terus dilakukan dalam kegiatan operasional UMKM. Saat ini bagi Usaha Kecil Dan Menengah Di Kabupaten Balangan Gaya Pola Pendampingan menjadi kebutuhan dasar bagi UMKM terutama dalam segala aspek aktifitas organisasi. Mengingat UMKM belum memiliki strategi yang jelas dan tepat dalam bersaing di pasar, sehingga nantinya diharapkan mampu bersaing di pasar local maupun tingkat Nasional.

Pola Pendampingan Terhadap pengembangan Jejaring pasar disini adalah merupakan aktivitas yang selalu dilakukan oleh kelompok-kelompok sosial seperti pengajaran, pengarahan atau pembinaan dalam kelompok dan bisa menguasai, mengendalikan serta mengontrol orang-orang yang mereka dampingi. Karena dalam pendampingan lebih pada pendekatan kebersamaan, kesejajaran, atau kesederajatan kedudukan khususnya dalam persaingan Bisnis dilihat dari aspek kualitas pelayanan, penciptaan produk, penjualan, dan strategi marketing lainnya sehingga diharapkan UMKM ini akan bias terus berkembang dengan baik.

Pengaruh Kemampuan Manajemen terhadap Pengembangan Pasar pada Usaha Kecil Dan Menengah Di Kabupaten Balangan

Berdasarkan hasil uji hipotesis, dapat disimpulkan bahwa Kemampuan Manajemen berpengaruh positif signifikan terhadap Pengembangan Pasar pada Usaha Kecil Dan Menengah Di Kabupaten Balangan. Hasil ini menunjukkan bahwa Kebanyakan responden setuju tentang Kemampuan Manajemen yang terus dilakukan merupakan kurangnya memahami kinerja yang diharapkan dari posisinya sebagai seorang pimpinan kelompok kerja, profesionalisme dalam bekerja rendah, jalur komunikasi yang kurang baik, kurang memahami peran manajerial, tidak mempunyai keterampilan manajerial yang diperlukan untuk menghasilkan kinerja manajerial yang ditargetkan, kompetensi diri rendah, dan lemah dalam hal memotivasi atau menggerakkan orang-orang yang dipimpinnya dengan baik pada Usaha Kecil Dan Menengah Di Kabupaten Balangan cenderung akan meningkatkan Pengembangan Pasar Karyawan terhadap Usaha Kecil Dan Menengah Di Kabupaten Balangan. Hasil penelitian ini mendukung penelitian Hasil ini sejalan dengan 
penelitian Eka Dwi Puji Astuti, 2015, dengan judul Pengaruh Kompetensi SDM, Pola Pendampingan Pemerintah dan Fungsi Manajerial Terhadap Pengembangan Pasar UKM di Kabupaten Banjar. hasil penelitian ini mengemukakan bahwa semua variabel bebas seperti kompetensi SDM, pola pendampingan pemerintah dan fungsi manajerial berpengaruh signifikan secara parsial terhadap variabel terikat terhadap Pengembangan Pasar UKM di Kabupaten Banjar.

Kemampuan Manajemen dalam Usaha dalam pengembangan Pasar UMKM di kabupaten Balangan disini adalah peran dan cara sistematis untuk mempersiapkan kemungkinan pertumbuhan yang potensial, bantuan dan juga pengawasan terhadap penerapan peluang pengembangan usaha namun tidak mencangkup keputusan mengenai strategi dan pelaksanaan kesempatan pengembangan usaha. Perlunya pengembangan usaha bagi UMKM menyangkut kelangsungan hidup dan pengembangan usaha dimana dituntut pelaku Usaha UMKM selalu berusaha dalam membenahi implementasi kerja baik sekarang ataupun kemudian hari dengan cara menyampaikan informasi yang dapat mempengaruhi sikap juga kemampuan.

\section{Pengaruh Pola Pendampingan terhadap Pengembangan Pasar pada Usaha Kecil Dan Menengah Di Kabupaten Balangan}

Berdasarkan hasil uji hipotesis, dapat disimpulkan bahwa Pola Pendampingan berpengaruh positif signifikan terhadap Pengembangan Pasar pada Usaha Kecil Dan Menengah Di Kabupaten Balangan. Hasil ini menunjukkan bahwa kebanyakan respondent Usaha Kecil Dan Menengah Di Kabupaten Balangan setuju Pendamping bagi UMKM yang belum memiliki kemampuan dan teknik dalam berkomunikasi yang baik, Pendamping bagi UMKM belum mampu membuat progam kerja, Pendamping bagi UMKM yang belum menguasai dan menggunakan teknologi dalam bidang pekerjaan, Ketersediaan tenaga pendamping masih terbatas dibanding dengan wilayah kerjanya, pendamping bagi UMKM yang belum mampu memberikan informasi yang dibutuhkan dan masih banyaknya sikap dari tenaga pendamping yang tidak professional. Hasil ini berkesesuaian dengan penelitian Eka Dwi Puji Astuti, 2015, dengan judul Pengaruh Kompetensi
SDM, Pola Pendampingan Pemerintah dan Fungsi Manajerial Terhadap Pengembangan Pasar UKM di Kabupaten Banjar. hasil penelitian ini mengemukakan bahwa semua variabel bebas seperti kompetensi SDM, pola pendampingan pemerintah dan fungsi manajerial berpengaruh signifikan secara parsial terhadap variabel terikat terhadap Pengembangan Pasar UKM di Kabupaten Banjar.

Perlunya penerapan system Pola Pendampingan yang baik pada UMKM akan menaikkan Pengembangan sebuah usaha dan ini merupakan tanggung jawab para pengusaha UMKM yang memerlukan pandangan yang maju, dukungan dan juga daya cipta. Umumnya, dalam mengembangkan usahanya para UMKM dituntut untuk bisa melihat peluang yang orang lain tak bisa melihatnya, tak bisa mengambil peluang, mengawali dan menjalankan usahanya dengan baik. Dengan melakukan pengembangan usaha maka UMKM akan mengerahkan seluruh pikiran dan juga tenaga untuk bisa memperbaiki kinerja Usaha mereka dengan cara melakukan perluasan dan meningkatkan mutu dan jumlah produksi.

\section{Pengaruh Jejaring Pasar terhadap Pengembangan Pasar pada Usaha Kecil Dan Menengah Di Kabupaten Balangan}

Berdasarkan hasil uji hipotesis, dapat disimpulkan bahwa Jejaring Pasar berpengaruh positif signifikan terhadap Pengembangan Pasar pada Usaha Kecil Dan Menengah Di Kabupaten Balangan. Hasil ini menunjukkan bahwa kebanyakan para respondent setuju bahwa Usaha Kecil Dan Menengah Di Kabupaten Balangan harus terus meningkatkan jejaring pasarnya melalui pemahaman nilai keunggulan produk /layanan kita, targetkan segmentasi pasa yang sfesifik, mengenal raga sumber pendapatan usaha, kenali ragam jalur distribusi untuk memperluas pasar, kelola hubungan pelanggan dengan baik, memahami manajemen pemasaran melalui $4 \mathrm{P}$ (Price, Place, Product And Promotion), dan Memanfatkan digital marketing secara optimal. Hasil ini juga sejalan dengan penelitian Wulandari, 2012 dengan judul Pengaruh Kompetensi SDM, Kemampuan manajerial dan Peran Pendampingan Pemerintah Terhadap jejaring pasar dan Pengembangan Usaha UKM di Kabupaten Sleman Yogyakarta. hasil penelitian ini mengemukakan bahwa semua variabel bebas seperti kemampuan manajerial, peran 
pendampingan pemerintah dan Jejaring pasar secara parsial berpengaruh signifikan baik secara langsung dan tidak langsung terhadap terhadap pengembangan usaha UKM di Kabupaten Sleman Yogyakarta.

Membangun jejaring pasar yang baik akan berdampak terhadap pengembangan pasar, hal ini akan ditandai dengan bisnis semakin terbuka luas dengan menggunakan jaringan bisnis sosial sebagai sarana menumbuhkan lingkaran kontak bisnis mereka dan mempromosikan diri mereka sendiri secara terbuka. Secara umum penegembangan jejaring pasar ini memungkinkan para UMKM Kabupaten Balangan untuk membangun lingkaran bisnis mereka dari mitra bisnis mereka yang saling mempercayai dan menguntungkan. Jejaring pasar disini merupakan seperangkat pembeli aktual dan juga potensial dari suatu produk atau jasa. Ukuran dari pengembangan pasar itu sendiri tergantung dengan jumlah orang yang menunjukkan tentang kebutuhan, mempunyai kemampuan dalam bertransaksi. Banyak UMKM yang memandang bahwa penjual dan pembeli sebagai sebuah pasar, dimana penjual tersebut akan mengirimkan produk serta jasa yang mereka produksi dan juga guna menyampaikan atau mengkomunikasikan kepada pasar. Sebagai gantinya, mereka akan mendapatkan uang dan informasi dari pasar tersebut.

\section{Pengaruh tidak langsung Kemampuan Manajemen terhadap Jejaring Pasar pada Usaha Kecil Dan Menengah Di Kabupaten Balangan melalui Pengembangan Pasar sebagai variabel intervening}

Pengaruh Kemampuan Manajemen terhadap Jejaring Pasar pada Usaha Kecil Dan Menengah Di Kabupaten Balangan dengan Pengembangan Pasar sebagai variabel intervening menunjukkan hubungan yang positif signifikan. Pengujian hipotesis keenam ini dilakukan dengan menggunakan perhitungan Sobel Test. Hal ini berarti bahwa parameter mediasi tersebut signifikan. Maka model pengaruh tidak langsung dari variabel Kemampuan Manajemen terhadap Jejaring Pasar pada Usaha Kecil Dan Menengah Di Kabupaten Balangan melalui Pengembangan Pasar sebagai variabel intervening dapat diterima. Hasil ini sejalan dengan penelitian Wulandari, 2012 dengan judul Pengaruh Kompetensi SDM, Kemampuan manajerial dan Peran Pendampingan
Pemerintah Terhadap jejaring pasar dan Pengembangan Usaha UKM di Kabupaten Sleman Yogyakarta. hasil penelitian ini mengemukakan bahwa semua variabel bebas seperti kemampuan manajerial, peran pendampingan pemerintah dan Jejaring pasar secara parsial berpengaruh signifikan baik secara langsung dan tidak langsung terhadap terhadap pengembangan usaha UKM di Kabupaten Sleman Yogyakarta.

Proses peningkatan Kemampuan Manajemen melalui Penaingkatan Kemampuan intelektual yaitu memahami kinerja yang diharapkan dari posisinya sebagai seorang pimpinan kelompok kerja, profesionalisme dalam bekerja rendah, jalur komunikasi yang kurang baik, kurang memahami peran manajerial, tidak mempunyai keterampilan manajerial yang diperlukan untuk menghasilkan kinerja manajerial yang ditargetkan, kompetensi diri rendah, dan lemah dalam hal memotivasi atau menggerakkan orang-orang yang dipimpinnya dengan baik tentunya apabila hal hal ini di tingkatkan terus akan menaikkan Pengembangan Pasar melalui peningkatan Jejaring Pasar Usaha Kecil Dan Menengah Di Kabupaten Balangan.

Pengaruh tidak langsung Pola Pendampingan terhadap Jejaring Pasar pada Usaha Kecil Dan Menengah Di Kabupaten Balangan melalui Pengembangan Pasar sebagai variabel intervening

Pengaruh Pola Pendampingan terhadap Jejaring Pasar pada Usaha Kecil Dan Menengah Di Kabupaten Balangan dengan Pengembangan Pasar sebagai variable intervening menunjukkan hubungan yang positif namum belum signifikan. Pengujian hipotesis ketujuh ini dilakukan dengan menggunakan perhitungan Sobel Test. Hal ini berarti bahwa parameter mediasi tersebut tidak signifikan. Maka model pengaruh tidak langsung dari variabel Pola Pendampingan terhadap Jejaring Pasar pada Usaha Kecil Dan Menengah Di Kabupaten Balangan melalui Pengembangan Pasar sebagai variable intervening tidak dapat diterima. Wulandari, 2012 dengan judul Pengaruh Kompetensi SDM, Kemampuan manajerial dan Peran Pendampingan Pemerintah Terhadap jejaring pasar dan Pengembangan Usaha UKM di Kabupaten Sleman Yogyakarta. hasil penelitian ini mengemukakan bahwa semua variabel bebas seperti kemampuan manajerial, peran 
pendampingan pemerintah dan Jejaring pasar secara parsial berpengaruh signifikan baik secara langsung dan tidak langsung terhadap terhadap pengembangan usaha UKM di Kabupaten Sleman Yogyakarta.

Akan tetapi perlu diperhatikan Proses peningkatan Pola Pendampingan dapat dilakukan dengan penerapan Pendamping bagi UMKM yang belum memiliki kemampuan dan teknik dalam berkomunikasi yang baik, Pendamping bagi UMKM belum mampu membuat progam kerja, Pendamping bagi UMKM yang belum menguasai dan menggunakan teknologi dalam bidang pekerjaan, Ketersediaan tenaga pendamping masih terbatas dibanding dengan wilayah kerjanya, pendamping bagi UMKM yang belum mampu memberikan informasi yang dibutuhkan dan masih banyaknya sikap dari tenaga pendamping yang tidak professional sehingga apabila hal hal ini terus di perbaiki maka akan menaikkan Pengembangan Pasar melalui peningkatan Jejaring Pasar Usaha Kecil Dan Menengah Di Kabupaten Balangan.

\section{PENUTUP}

\section{Kesimpulan}

Berdasarkan hasil penelitian dan pembahasan yang telah dilakukan mengenai pengaruh Kemampuan Manajemen dan Pola Pendampingan terhadap Pengembangan Pasar dengan Jejaring Pasar sebagai variabel intervening pada Usaha Kecil Dan Menengah Di Kabupaten Balangan, dengan menggunakan analisa jalur/ path analysis dengan program SmartPLS maka dapat ditarik kesimpulan sebagai berikut :

1. Hasil uji pertama menyatakan bahwa ada pengaruh positif dan signifikan antara Kemampuan Manajemen terhadap Pengembangan Pasar.

2. Hasil Uji Kedua menyatakan bahwa ada pengaruh positif dan signifikan antara Pola pendampingan terhadap pengembangan usaha pada UKM di Kabupaten Balangan.

3. Hasil Uji Ketiga menyatakan bahwa ada pengaruh positif dan signifikan antara Kemampuan manajemen terhadap jejaring pasar pada UKM di Kabupaten Balangan.

4. Hasil Uji keempat menyatakan bahwa ada pengaruh positif dan signifikan antara Pola pendampingan terhadap jejaring pasar pada UKM di Kabupaten Balangan.
5. Hasil Uji kelima menyatakan bahwa ada pengaruh positif dan signifikan antara Jejaring pasar terhadap pengembangan usaha pada UKM di Kabupaten Balangan.

6. Hasil Uji keenam menyatakan bahwa ada pengaruh positif dan signifikan antara kemampuan manajemen terhadap pengembangan usaha pada UKM di Kabupaten Balangan, dimediasi oleh variabel jejaring pasar.

7. Hasil Uji ketujuh menyatakan bahwa ada pengaruh positif dan signifikan antara pola pendampingan terhadap pengembangan usaha pada UKM di Kabupaten Balangan, dimediasi oleh variabel jejaring pasar..

\section{Saran}

Berdasarkan kesimpulan diatas, dapat dikemukakan beberapa saran yang diharapkan dapat bermanfaat bagi Usaha Kecil Dan Menengah Di Kabupaten Balangan. Adapun saran yang diberikan antara lain:

1. Kemampuan Manajemen dapat menaikkan jejaring pasar dan pengembangan usaha pada Usaha Kecil Dan Menengah Di Kabupaten Balangan umumnya sudah pada kategori bagus. Namun sebagian besar UMKM Masih Banyak yang belum mampu menaikkan kemampuan manajemennya dan ini diharapkan menjadi konsen pemerintah daerah untuk bias terus mengambangkan Usaha UMKM.

2. Dari hasil penelitian dapat dilihat bahwa Gaya Pola Pendampingan memberikan pengaruh terhadap jejaring pasar dan pengembangan usaha Usaha Kecil Dan Menengah Di Kabupaten Balangan perlunya konsistensi dari pemerintah daerah dalam penerapan pola pendampingan akan sangat di butuhkan UMKM dalam terus berkembang dan bertumbuh dalam berbisnis

3. Agar Jejaring Pasar dapat lebih meningkat dan menaikkan pengembangan pasar, perlu ditingkatkan beberapa aspek berikut pertama Segi Ekonomi yaitu Merupakan tempat transaksi antara produsen dan konsumen yang merupakan komoditas untuk mewadahi kebutuhan sebagai demand dan suplai. Kedua aspek Segi Sosial Budaya Merupakan kontrak sosial secara langsung yang menjadi tradisi suatu masyarakat yang merupakan interaksi 
antara komunitas pada sektor informal dan formal. Dan ketiga Segi Arsitektur yaitu Menunjukkan ciri khas daerah, yang menampilkan bentuk-bentuk fisik bangunan dan artefak yang dimiliki.

4. Pentingnya Peningkatan Pengembangan Pasar yang perlu dicermati dan tentunya dengan mempertimbangkan aspek lain di luar penelitian ini, karena dalam persaingan ini pasar terus berkembang dan tentunya menuntut UMKM bisa terus mengiktui perkambangan pasar ini dengan memperhatikan dan mengikuti aspek2 lain dalam pengembangan pasar.

5. Hendaknya para peneliti selanjutnya lebih mengembangkan ruang lingkup penelitian yang lebih lagi, mengingat penelitian yang dilaksanakan ini belum sepenuhnya bisa menggambarkan peningkatan Produktifitas dan Jejaring Pasar. Dalam proses pengumpulan data, hendaknya menggunakan teknik yang diperkirakan dapat lebih optimal dalam mendapatkan data yang diperlukan.

\section{Daftar Pustaka}

Arikunto, 2010, Metode Penelitian Dan Riset, Rineka Cipta, Jakarta

Atom Ginting, 2015,

Manajemendan

Kepemimpinan, Gramedia, Jakarta

Basri, 2009, Manajemen Sumbe Daya Manusia, PT. Rajawali Press, Jakarta

Bintan, 2010, Pendampingan dan Penyuluhan, Nova, Bandung

Butarbutar. Binsar, 2011, Manajemen Bisnis, Media Pustaka, Jakarta

Dimas, 2010, Pengantar Ilmu Manajemen dan Kepersonalian. Jilid I. Jakarta: Prenhallindo.

Deptan, 2010, Ruang Lingkup Pengelolaan UMKM, GlobalMedia, Surabaya

Edi Suharto, 2009, Ruang Lingkup UMKM, Media Jaya, Surabaya

Eka Dwi Puji Astuti, 2015, Pengaruh Kompetensi SDM, Pola Pendampingan Pemerintah dan Fungsi Manajerial Terhadap Kemajuan usaha UKM di Kabupaten Banjar, Unlam, Banjarmasin

Gamawan, 2012, Manjemen Kepersonalian dan SDM, Balai Pustaka, Jakarta

Hasibuan, 2010, Manajemen SDM dan Kepersonalian, Jilid IV, BPFE, Yogyakarta
Husnan dan Pandjoro, 2009, Manajemen SDM dan Perkantoran, Rineka Cipta, Jakarta

Handoko. T. Hani, 2012, Manajemen SDM dan Kepersonalian, Edisi Revisi, BPFE, Yogyakarta

Irawan, 2011, Manajemen SDM, Buana Karya, Surabaya

Kolter Phillip \& Keller, 2012, Marketing, Buana Putra, Jakarta

Lesmana, 2011, Manajemen Sumber Daya Manusia, Alfabetha, Bandung

Mahmud Mach Foedz, 2010, Bisnis Usaha Menengah Mikro Kecil, Rineka Cipta, Jakarta

Malita, 2011, Binis Online, Gramedia, Jakarta

Martoyo, 2012, Manajemen, Balai Pustaka, Jakarta

Muliawan, 2010, Manajemen UMKM, Balai Pustaka, Jakarta

Marbun, 2013, Manajemen Usaha Kecil dan Bisnis Rumahan, Media Pustaka, Jakarta

Muchdarman, 2010, Manajemen SDM, Rineka Cipta, Jakarta

Mursaha, 2010, Permasalahan dan Ruang Lingkup Pendamping dan Tenaga Penyuluh, Bumi Aksara, Jakarta

Nawawi, 2013, Manajemen SDM, Salemba Empat, Yogyakarta

Nitisemito, 2011, Manajemen SDM dan Personalia, Ghalia Indonesia, Jakarta

Pratisto, Arif, 2011, Cara Mudah Mengatasi Statistik dan Rancangan Percobaan dengan SPSS 12, PT Elex Media Komputindo Kelompok Gramedia, Jakarta

Pandji Anoraga, 2010, Manajemen Bisnis, Rineka Cipta, Jakarta

Panggabean, 2012, Manajemen Sumber Daya Manusia, Bumi Aksara, Jakarta

Prayitno,2010, Manajemen SDM, Erlangga, Jakarta

Permata, 2013, Manajemen UMKM dan Koperasi, Rineka Cipta, Jakarta

Riduan, 2010, Manajemen Usaha Kecil, Balai Pustaka, Jakarta

Riyanto, 2012, Manajemen SDM dan Keorganisasian, Bumi Aksara, Jakarta

Rivai, 2013, Azaz-azaz Manajemen Perusahaan, Alfabeta, Bandung

Rudiantono, 2013, Kinerja UKMK di Masa Era Globalisasi, Rineka Cipta, Jakarta 
Satriawan, 2011, Manajemen SDM, Bumi Daya, Jakarta

Solimun, 2013, Metodologi dan Komputer Statistik, Media Pustaka, Jakarta

Sugiyono, 2009, Metedologi Penelitian, Rineka Cipta, Jakarta

Sutrisno, 2013, Pengaruh Kompetensi Penglola UKM, Peran Pendampingan dan Pengelolaan Manajemen Terhadap Kinerja UKM di Kota Banjarmasin, Unlam, Banjarmasin

Susilo.H, 2011, Manajemen Kepegawaian, Liberty, Jakarta

Sudjatmoko Agung, 2009, Cara Cerdas Menjadi Pengusaha Hebat, Rineka Cipta, Jakarta

Suparno, 2012, Buku Penelitian, Rajawali Press, Jakarta

Siagian F. Sondakh, 2011, Manajemen, Edisi revisi, Balai Pustaka, Jakarta

Suryanto.Bambang,2019, Manajemen Bisnis, Gava Media, Surabaya

Simamora Hendry, 2012, Manajemen Sumber Daya Manusia, Fakultas Ilmu Administrasi Universitas Brawijaya, Malang

Thoha. Miftah, 2011, Manajemen SDM, Rineka Cipta, Jakarta

Undang-undang Nomor 20 tahun 2008 tentang Usaha Mikro, Kecil, dan Menengah, Jakarta

Ulber Silalahi, 2012, Manajemen dan Pola-pola Kepemimpinan, Libertya, Jakarta

Umar.Hamzah, 2012, Manajemen dan Keorganisasian, Erlangga, Jakarta

Wahjosumidjo, 2011, Azaz-azaz Kepemimpinan, Balai Pustaka, Jakarta

Wibowo, 2012, Manajemen SDM, Rineka Cipta, Jakarta

Winardi, 2010, Manajemen, Jilid Kedua, Nova, Bandung

Wiryasaputra, 2013, Efektivitas Penyuluh / Pendamping UMKM, Prima Jaya, Surabaya

Wulandari, 2012 Pengaruh Kompetensi SDM, Kemampuan manajerial dan Peran Pendampingan Pemerintah Terhadap Pengembangan Usaha UKM di Kabupaten Sleman Yogyakarta, UGM Yogyakarta

Yulia Herwaty, 2011, Manajemen Pendampingan Usaha Kecil, Rineka Cipta, Jakarta 